Saudi Journal of Business and Management Studies Abbreviated Key Title: Saudi J Bus Manag Stud ISSN 2415-6663 (Print) |ISSN 2415-6671 (Online) Scholars Middle East Publishers, Dubai, United Arab Emirates Journal homepage: https://saudijournals.com/sibms

Original Research Article

\title{
What Determines Bank's Profitability? Evidence from GCC Banking Sector
}

\author{
Muaadh AYA. Alhabri ${ }^{1 *}$, S.N Jha ${ }^{2}$ \\ ${ }^{1}$ Research Scholar, Faculty of Commerce, Banaras Hindu University, India \\ ${ }^{2}$ Professor, Faculty of Commerce, Banaras Hindu University, India
}

DOI: $10.36348 /$ sjbms.2020.v05i03.004 $\quad$ |Received: 04.03.2020 | Accepted: 13.03.2020| Published: 18.03 .2020

*Corresponding author: Muaadh Abdulrahman Yahya Ali Alhabri

\section{Abstract}

The main aim of this study is to examine the variables that affect the profitability of GCC banks. The current study provides evidence of important bank-specific variables that have affected GCC banks' profitability by analyzing balanced panel data for 2011 to 2018. Data pertaining was extracted from the annual reports of the selected listed banks. This paper puts into relief the determinants of the profitability of the commercial banking sector of the GCC. The sample compresses 20 GCC banks. The paper examines internal variables (company-level indicators), which include adequacy, liquidity, credit risk, efficiency cost, net credit facilities and bank size. Panel data regression analysis is used for the analysis. Based on the empirical analysis, the cost efficiency, nontraditional revenue sources, and high asset quality are the most significant bank-specific variables, and bank managers that can use them to make future policy decisions. The model generated in the study can explain a greater than $75 \%$ change in the total variance of various measures of profitability. This paper adds to the body of knowledge by empirically highlighting the most recent and extensive panel data for the entire banking sector of the GCC. The paper uses a range of independent variables for the internal -specific variables.

Keywords: Bank Profitability, Bank Specific Variables, Commercial Banks, GCC Banks.

Copyright @ 2020: This is an open-access article distributed under the terms of the Creative Commons Attribution license which permits unrestricted use, distribution, and reproduction in any medium for non-commercial use (NonCommercial, or CC-BY-NC) provided the original author and source are credited.

\section{INTRODUCTION}

Banking industry is the core of any economic system and plays its essential role in the economic growth of a nation. Global savings can only be deployed for productive industries through commercial banks that boost a nation's economic rate of growth. The fundamental purpose of bank management is to generate profit as the essential requirement for business conduct [1]. Also stabilize a country's financial system in profitable commercial banks. Commercial banks have a major role to play in accepting deposits from the general public and advancing loans. In the past, researchers have done a lot of work on commercial banks ' profitability determinants of commercial banks. Some researchers used only bank features or internal variables in their study, but some used macroeconomic variables or external factors as well as internal factors in their research. Saira Javaid et al. [2] argued that bank size or total assets do not result in commercial bank profitability, but equity and deposits have a major impact on commercial bank profitability.

Research on the determinants of bank profitability has typically focused on both the returns on bank assets and equity, and the net interest margins as dependent variables. More recent studies have expanded the number of factors considered. Thus, scholars [3-6] have examined the effect of bank-specific (i.e. capital ratio, operational efficiency, bank size) industryspecific (i.e. ownership and concentration) and macroeconomic (i.e. inflation and cyclical output) determinants on bank performance.

Strong banking can deal with adverse crises and contribute to the stabilization of the economic industry. Various variables influence financial institutions, including internal and external 
variables that directly influence efficiency. Internal variables such as management choices on (balance sheets and/or profit and loss accounts), assets, bank size, risk management and expenditure management directly affect the profitability of the bank because most of these variables stay confidential. Other internal variables, such as credit or liquidity, are considered as bank-specific factors strongly related to bank administrators, especially risk management. Banks continue to grow economically through tools to diversify risks and increase liquidity [7]. There is a need for risk assessment in the banking sector as a result of its nature. The two principal factors of economic crisis are poor asset quality and low liquidity and are the essential loan risk and liquidity risk sources, and researchers have focused attention on assessing their effect on banking income development.

The external factors influencing bank profitability are depicted in financial circumstances and institutional context. Macro-economic conditions such as inflation, interest rates and cyclical production, and market features such as market concentration, size of sector and status of property. One of the fastest increasing banking sectors in the world, the GCC countries. Commercial banks working in the competitive setting are likely to be more effective in the region in the near future. Over the past decade, the GCC banking industry has experienced steady growth and stability. Recent stress studies also show that GCC banks are sound and well-equipped to resist any shocks. In addition, the banking sector of the GCC plays a very significant role in promoting the gross domestic product and operates as an engine to help the economy of the GCC. However, the effective functioning of the banking sector has become one of the most significant goals of economic reforms in GCC countries. Profitability and effectiveness also became one of the difficulties encountered by banks to improve their economic positions to satisfy the hazards connected with openness and globalization.

The significance of bank profitability can be valued at the economy's micro and macro levels. At the micro level, profit is the fundamental prerequisite for a successful banking institution and the cheapest source of capital. It is not merely a consequence, but also a requirement for effective banking in area of increasing competition on financial markets. Here, the fundamental goal of a bank leadership is to achieve profit as the vital requirement for any company [8]. Moreover, a sound and sustainable banking sector is better at the macro level to resist adverse shocks and add to the stability of the financial system. The significance of bank profitability at both micro and macro level has produced scientists, universities, bank management, and regulatory agencies interested in variables that influence bank profitability [4].
Previous studies [9-12] on banks profitability are usually expressed as a function of internal and external determinants. The internal determinants refer to the factors that are originated from banks accounts (balance sheet and/or profit and loss accounts) and therefore, they could be termed as micro or bankspecific determinants of profitability. The external determinants are variables that are not related to the bank management. They reflect the economic and the legal environment that affect the operation and performance of financial institutions.

\section{LITERATURE REVIEW}

A substantial number of empirical studies have been conducted on the banking sectors of developed countries. However, there is a dearth of studies on Middle Eastern banks, and on GCC banks in particular, in the literature. The majority of existing studies focus on evaluating the performance of commercial banks in comparison to that of Islamic banks. Very few deals with the determinants of the banks' profitability. For instance, using data from 43 Islamic banks, Hussein A. Hassan al-Tamimi [13] analyzed the performance of UAE banks, including Islamic and conventional banks, between 1996 and 2008; the study found that liquidity and concentration were the most significant determinants of conventional national banks' performance. On the other hand, cost and number of branches were the most significant determinants of Islamic banks' performance.

Several studies have focused on bank profitability in individual countries. Single country studies are of Sufian \& Habibullah [5];Garcia-Herrero, Gavila', \& Santaba' rbara [6]; Heffernan \& Fu [5]; Lee \& Hsieh [14]; Tan and Floros [15]; Alexiou \& Sofoklis [6]; Athanasoglou et al. [4], Mamatzakis \& Remoundos [8]; Bhatia, Mahajan, \& Chander [16]; Karimzadeh, Akhtar \& Karimzadeh [17]; Kenya, Kaganda [18]; Agustini [19]; Sastrosuwito \& Suzuki [20]; Liu \& Wilson [21];Almumani [17]; Guru [14].

Other studies have examined profitability across multiple countries.

These cover Athanasoglou, Delis, \& Staikouras [4]; Bourke [10]; Demirguc-Kunt \& Huizinga [12]; Goddard, Molyneux, \& Wilson [21]; Olson \& Zoubi [22]; Pasiouras \& Kosmidou [23]; Perera, Skully, \& Chaudhry, [17]; Staikouras \& Wood [3]; Shen, Chen, Kao, \& Yeh, [6]; van Ommeren [18]; Flamini, McDonald, \& Schumacher [6]; Molyneux \& Thornton [11]; Mirzaei \& Mirzaei, [24]; Short [9]; Francis, 2013 and Wahidudin, Subramanian, \& Kamaluddin [14].

Syafri [15] used pooling data from commercial banks to examine the profitability of Indonesian commercial banks listed on the stock exchange for the period 2002 to 2011. He introduced the model of pooling information regression in which the return on 
property is dependent variable and internal and external determinants were used as independent variables. In his studies, he said that loaning to complete assets has a beneficial impact on profitability, while bank size and revenue ratio have a adverse impact, and economic growth and non-interest earnings to complete assets have no impact.

Ani, W.U et al. [20] explored the determinants of commercial bank's profitability in Nigeria for ten years from 2001 to 2010 including the sample of 147 banks. Pooled ordinary least square has been used to estimate the coefficient. Study discovers that bank size does not boost the profits of any commercial banks in Nigeria. Greater capital-asset ratio improves bank profitability.

Saira Javaid et al. [18] analyzed the profitability of top 10 Pakistan's commercial banks for the period 2004-2008. Pooled ordinary least square was used to verify the impact of internal variables including assets, loans, equity and deposits on banks ' profitability from dependent variable call return on assets (ROA) The research discovered that inner variables indicated above had an effect on the bank's profitability. Bank size or assets do not contribute to commercial bank profitability, but equity and deposits have a important impact on the profitability of commercial banks.

Imad Z. Ramadan et al. [19] examined profitability determinants of 10 Jordanian banks for the period 2001-2010.The study used equity return (ROE) and asset return (ROA) as dependent variables and internal and external factors were used as independent variables and the type of data of Jordanian banks is penal data. Results indicated that Jordan banks ' profitability depends on well-capitalized banks, large loan operations, lower credit risk, and cost-management effectiveness. Findings also voiced that size does not boost Jordan banks ' profitability.

Fadzlan Sufian et al. [5] investigated bank profitability in Philippines for the period 1990-2005. Output paints a image that profitability variables have a significant effect on bank profitability. The research also indicates that if the expense-related conduct and credit risk improves the profitability of companies operating in Philippines decrees and the non-interest earnings and capitalization both have a favorable connection with the profitability of the bank. Inflation raises the profit of banks in Philippines declines during the research conducted.

Sehrish Gul, Faiza Irshad and Khalid Zaman $[22,27]$ used information from the top fifteen business banks operating in Pakistan's economy for the period 2005-2009 to test the connection between bank particular features and bank profitability. This study uses the Polled Ordinary Least Square technique to examine the impact of assets, loans, equity, deposits, economic growth, inflation and market capitalization on significant profitability blinkers such as return on investments (ROA), return on equity (ROE), return on capital employed (ROCE) and net interest margin (NIM) one by one. The study institutes that both internal and external factors have a strong influence on the profitability of the bank.

Paolo Saona Hoffmann [24] studied the determinants of banks profitability working in the US for the era 1995-2007. The research undertakes internal and external variables influencing bank profitability in the US economy. The research discovered that there is a adverse connection between the capital ratio and profitability that affirms the belief that banks are operating most closely and dismissing possibly lucrative trading possibilities. The price benefits due to the size of the bank do not influence the profitability of the US banking industry.

Syeda Anum Javed Bukhari [16] evaluated the internal and external factors affecting the profitability of 11 commercial banks operating in Pakistan for the period 2005-2009. The research applies the regression analysis to involve the outcome with the hypothesis. The results from this research paper are that internal variables have an effect on the profitability of commercial banks while external variables have no effect.

Khizar Ali et al. [25] evaluated the profitability factors affecting the profit of the 22 government and private commercial banks operating in Pakistan for the period 2006-2009. The research used descriptive statistics, correlation and regression analysis. Return on assets (ROA) and return on equity (ROE) were used as dependent variables, while internal and external factors were used as independent variables. The findings indicate that the profitability improves when financial development rises. And on the other hand, when the credit risk rises the profitability declines.

Deger Alper [25] tested Turkey's internal and external bank profitability factors for the 2002-2010 period. In this research, asset return (ROA) and equity return (ROE) are both dependent variables and inner and external factors. Profitability rises when noninterest earnings and asset size rises. And the real interest rate on external variables has a beneficial impact on profitability.

Dr. Srinivas Madishhetti et al. [17] evaluated the factors affecting Tanzania commercial banks profitability for the period 2006-2012.Internal determinants use factors such as liquidity risk, credit risk, working effectiveness, company assets and capital adequacy and internal determinants use the variables GDP growth rate and inflation rate. All these factors are autonomous. The research discovered that internal variables determine the profitability of the bank while 
external factors do not affect the profitability of commercial banks.

Abuzar [17] analyzed the profitability factors of Islamic banks operating in Sudan. This research find that only internal variables have a substantial effect on the profitability of commercial banks. Cost, liquidity and bank size have a positive connection with bank profitability. Macroeconomic or external variables have no significant effect on profitability.

Alkassim [7] studied the profitability of Islamic and conventional banks in GCC countries for the period 1997-2004. He examined both internal and external factors affecting the profitability of Islamic and conventional banks. This research showed that standard banks ' asset quality is better than others. Interest-free loans have a negative effect on Islamic bank profitability and complete expenses on the profitability of standard banks operating in GCC countries.

Alpera and Anbar [25] evaluated the internal and external variables of Turkey's commercial banks for the period 2002-2010. The findings that non-interest earnings and bank size have a beneficial effect on bank profitability. And on the side of macroeconomic or external variables, only real interest rates favorably impact the profitability of commercial banks.
Vong and chan [26, 28, 29] evaluated the effect of internal and external variables on the profitability of the Macau banking industry over a 15year period. This research discovered that elevated capitalization leads to elevated profitability and bank size improves profitability, which means banks enjoy the advantage of economies of scale. And on the other side, the credit loss clause has an unfavorable effect on the profitability of the Macau banking industry.

\section{RESEARCH METHODOLOGY Sample selection and data collection}

The purpose of this study is to highlight the factors which determine bank profitability. The dependent variable is bank's profitability which is measured by Return on Assets (ROA) and Return on Equity (ROE) while the independent variables are Capital adequacy, Credit risk, Management efficiency, Liquidity risk, Net credit facilities to total assets. Moreover, the control variable in this study consist of Bank' size. Twenty listed banks from GCC countries have selected by market capitalization covering all five GCC countries. The sample data have been collected for eight years from 2011 up to 2018. Banks specific characters (independent variable) are hand-collected from the Banks official websites and annual reports.

\section{Variable Description}

Table-1: Variable description

\begin{tabular}{|l|l|l|l|}
\hline Symbol & Variables & Proxy & Expected Relation \\
\hline Dependent Variable & & & \\
\hline ROA & Return on Assets & Net Profit / Total Assets & \\
\hline ROE & Return on Equity & Net Profit/Equity & \\
\hline Independent VARIABLE & & Equity/ Total Assets & $+/-$ \\
\hline Adequacy & Capital Adequacy & $\begin{array}{l}\text { Impaired Loans (NPls)/Gross } \\
\text { Loans }\end{array}$ & - \\
\hline Crisk & Credit Risk & Cost to Income Ratio & - \\
\hline Efficiency & Management Efficiency & Loans/Customer Deposits & - \\
\hline Lrisk & Liquidity Risk & & $+l-$ \\
\hline Nca & $\begin{array}{l}\text { Net Credit Facilities to Total } \\
\text { Assets }\end{array}$ & & \\
\hline Control Variable & & Logarithm of Total Assets & $+/-$ \\
\hline Size & Bank Size & & \\
\hline
\end{tabular}

\section{Model Specifications and Econometric Tools}

The current study uses a panel data of 20 banks for a period of 8 years from 2011 to 2018 for GCC Banks. There are two advantages of adopting the panel data analysis approach which has been confirmed in many studies. Firstly, it monitors for individual heterogeneity and multicollinearity Athanasoglou et al.
[4]. Secondly, its adequacy and efficiency of econometric estimates over pure time-series or pure cross-sectional data analysis techniques Bourke, [10]. The present study applies the regression to study the impact of bank's internal factors on its profitability of GCC countries. To achieve the study objectives the following regression models are developed:

$\mathrm{ROA}_{\mathrm{it}=} \alpha+\beta_{1} \mathrm{AD}_{\mathrm{it}}+\beta_{2} \mathrm{CR}_{\mathrm{it}}+\beta_{3} \mathrm{EF}_{\mathrm{it}}+\beta_{4} \mathrm{LR}_{\mathrm{it}}+\beta_{5} \mathrm{NCA}_{\mathrm{it}}+\beta_{6} \mathrm{SI}_{\mathrm{it}}+\varepsilon_{\mathrm{it}}(1)$

$\mathrm{ROE}_{\mathrm{it}=} \alpha+\beta_{1} \mathrm{AD}_{\mathrm{it}}+\beta_{2} \mathrm{CR}_{\mathrm{it}}+\beta_{3} \mathrm{EF}_{\mathrm{it}}+\beta_{4} \mathrm{LR}_{\mathrm{it}}+\beta_{5} \mathrm{NCA}_{\mathrm{it}}+\beta_{6} \mathrm{SI}_{\mathrm{it}}+\varepsilon_{\mathrm{it}}$ (2) 
Where,

\begin{tabular}{|l|}
\hline$\alpha=$ intercept \\
\hline$\varepsilon_{\text {it }}=$ error term \\
\hline$\beta=$ beta $^{-}$ \\
\hline $\mathrm{ROA}_{\text {it }}=$ Return on asset \\
\hline $\mathrm{ROE}_{\text {it }}=$ Return on equity \\
\hline $\mathrm{AD}=$ is the capital adequacy for the banks \\
\hline $\mathrm{CR}=$ is the credit risk banks \\
\hline $\mathrm{EF}=$ is the bank's efficiency \\
\hline $\mathrm{LR}=$ is the liquidity risk for the banks \\
\hline $\mathrm{NCA}=$ is the net credit facilities to total assets for the banks \\
\hline $\mathrm{SI}=$ is the bank's size \\
\hline
\end{tabular}

\section{Summary Statistics}

Table 2 reports the descriptive statistics of all the dependent and independent variables. The mean for ROA and ROE is 2.1 and 2.3 respectively. The maximum average for the independent variable goes to credit risk with 18.4. The density in the data set is measured through the standard deviation. The minimum stander deviation value goes to liquidity risk and net credit. Whereas, the maximum goes to capital adequacy.

Table-2: Descriptive statistics

\begin{tabular}{|l|l|l|l|l|}
\hline Dependent variable: Bank profitability & Min. & Max. & Mean & Std. Dev. \\
\hline ROA & 0.73 & 2.9 & 2.1 & .423 \\
\hline ROE & 0.67 & 1.7 & 2.3 & .482 \\
\hline Independent VARIABLE & & & & \\
\hline Adequacy & 16.3 & 24.56 & 17.3 & 7.23 \\
\hline Crisk & 8.23 & 14.52 & 18.4 & 6.98 \\
\hline Efficiency & 4.56 & 7.23 & 5.23 & 4.45 \\
\hline Lrisk & 7.38 & 11.34 & 8.12 & 3.56 \\
\hline Nca & 8.45 & 10.21 & 13.21 & 3.56 \\
\hline Control Variable & & & & \\
\hline Size & 2.4 & 4.87 & 4.56 & 2.34 \\
\hline
\end{tabular}

\section{RESULTS AND DISCUSSION \\ Correlation Analysis}

Table 3 explains the Pearson correlation test of all the independent variables used in the study. The test indicates that there is a positive and significance association between ROA and liquidity risk and the size of the banks. On the contrary, the result shows that there is negative and significance association between ROA and credit risk, efficiency and net credit facilities.
The test indicates that there is a positive and significance association between credit risk and liquidity risk. All the variables reflect correlation value of less than 0.5 and more than 0.5 among each other, indicating a variant level of multi-collinearity among variables. The results show that the data can be utilized for the regression because the problems do not exist among its variables.

Table-3: Correlation Matrix between variables

\begin{tabular}{|c|c|c|c|c|c|c|c|c|c|}
\hline & & ROA & ROE & Adeq. & Crisk & Eff. & Lrisk & Nca & Size \\
\hline \multirow[t]{2}{*}{ ROA } & correlation & 1 & & & & & & & \\
\hline & Sig. & & & & & & & & \\
\hline \multirow[t]{2}{*}{ ROE } & correlation & $.5247 * *$ & 1 & & & & & & \\
\hline & Sig. & .000 & & & & & & & \\
\hline \multirow[t]{2}{*}{ Adeq. } & correlation & -.132 & .063 & 1 & & & & & \\
\hline & Sig. & .253 & .567 & & & & & & \\
\hline \multirow[t]{2}{*}{ Crisk. } & correlation & $-.432 * *$ & .146 & -.023 & 1 & & & & \\
\hline & Sig. & .000 & .198 & .710 & & & & & \\
\hline \multirow[t]{2}{*}{ Eff. } & correlation & $-.247 *$ & -.72 & -.159 & .078 & 1 & & & \\
\hline & Sig. & .026 & .532 & .229 & .475 & & & & \\
\hline \multirow[t]{2}{*}{ Lrisk. } & correlation & $.412 * *$ & $.412 * *$ & -.233 & $.755 * *$ & $-.242 *$ & 1 & & \\
\hline & Sig. & .000 & .000 & .248 & .000 & .095 & & & \\
\hline \multirow[t]{2}{*}{ Nca. } & correlation & $-.245^{*}$ & -.75 & -.123 & $-.286^{*}$ & .048 & .096 & 1 & \\
\hline & Sig. & .027 & .534 & .342 & .012 & .325 & .453 & & \\
\hline \multirow[t]{2}{*}{ Size } & correlation & $.407 * *$ & $.423 * *$ & -.194 & -237 & $-.242 *$ & -.243 & -134 & 1 \\
\hline & Sig. & .000 & .000 & .237 & 0.23 & .067 & .024 & 0.28 & \\
\hline \multicolumn{4}{|c|}{ Variance Inflation Factor } & 1.0218 & 1.8124 & 1.0112 & 1.1951 & 2.6541 & 2.7950 \\
\hline
\end{tabular}




\section{The unit Root test}

The table4 shows the result of variables stationary. The stationary were examined using Augmented Dickey- Fuller (ADF) test and PhilipPerson test. The findings show that the data is stationary at first and second difference at $\alpha 1 \%, 5 \%$, and $10 \%$ level of significance respectively. Findings of both test at the levels shows that all the variable are stationary which lead to rejecting the unit root null hypothesis.

Therefore, the variable was then tested at the first difference and second difference. Table 4 shows the results of P-Values of ADF and Phillip-Person Test for all variables at the level and first difference.

Table-4: Unit root Test

\begin{tabular}{|l|l|l|l|l|}
\hline \multirow{2}{*}{ Variable } & \multicolumn{2}{|c|}{ ADF Test } & \multicolumn{2}{c|}{ Phillip-Person Test } \\
\cline { 2 - 5 } & First deference & second deference & First deference & second deference \\
& P value & t- statistic & t- statistic & t- statistic \\
& P value & P value & P value \\
\hline \multirow{2}{*}{ ROE } & 37.2639 & 0.0000 & 43.3272 & 0.0000 \\
& 0.0040 & 0.0000 & 0.0013 & 0.0000 \\
\hline \multirow{2}{*}{ Adeq. } & 39.4884 & 0.0000 & 46.3294 & 0.0000 \\
& 0.0058 & 0.0000 & 0.0007 & 0.0000 \\
\hline Crisk. & 38.0592 & 0.0000 & 48.8975 & 0.0003 \\
& 0.0087 & 0.0000 & 0.0974 & 0.000 \\
\hline \multirow{2}{*}{ Eff. } & 0.0036 & 0.0000 & 59.1034 & 0.000 \\
& 0.0000 & 0.0000 & 0.000 & 0.000 \\
\hline \multirow{2}{*}{ Lrisk. } & 0.0000 & 43.7792 & 0.000 & 59.1665 \\
& 0.0000 & 0.0016 & 0.000 & 0.000 \\
\hline \multirow{2}{*}{ Nca. } & 38.3432 & 51.6696 & 0.0000 & 61.2847 \\
\cline { 2 - 5 } & 0.0056 & 0.0000 & 0.0000 & 0.0000 \\
\hline \multirow{2}{*}{ Size } & 41.0342 & 0.0000 & 52.2314 & 0.0000 \\
\cline { 2 - 5 } & 0.0087 & 0.0000 & 0.000 & 0.0000 \\
\hline
\end{tabular}

\section{Regression Analysis}

Table5 includes the panel data regression results with the ROA and ROE as the dependent variable. The ROA was negatively related to the capital adequacy. A higher tier I capital ratio led to a low ROA. Diversification was positively related to the ROA, with the ratio of non-interest income to gross revenues being negatively related to the ROA. Conversely, the cost efficiency had a positive relationship to the ROA. The higher the cost to income ratio, the lower cost efficiency would be, bringing down the ROA of the banks. once more the net credit facility was a positively related to ROA and ROE.

The P-value is significant for credit risk, and credit risk inn ROA model. On the contrary the P-value is negative for cost of efficiency, liquidity risk, net credit facility and size of bank. For model (2) ROE, apart from credit facility and firm size, the others vaiable are positively associated with ROA which the P-value is less than 0.05 .

Table-5: Regression result

\begin{tabular}{|c|c|c|c|c|c|c|c|c|c|}
\hline \multicolumn{5}{|c|}{ Model (1) ROA } & \multicolumn{5}{|c|}{ Model (2) ROE } \\
\hline Variables & Coefficient & $\begin{array}{l}\text { St. } \\
\text { Error }\end{array}$ & $\begin{array}{l}\text { t- } \\
\text { statistic }\end{array}$ & Prob & Variables & Coefficient & $\begin{array}{l}\text { St. } \\
\text { Error }\end{array}$ & $\begin{array}{l}\mathrm{t}- \\
\text { statistic }\end{array}$ & Prob \\
\hline Adeq. & -0.0156 & 0.0143 & -2.2643 & 0.0435 & Adeq. & -0.02167 & 0.00234 & -3.3423 & 0.0078 \\
\hline Crisk. & -0.00253 & 0.0025 & -0.5634 & 0.0213 & Crisk. & -0.00421 & 0.00213 & -2.3421 & 0.0231 \\
\hline Eff. & -0.00235 & 0.0234 & -6.5647 & 0.2346 & Eff. & -0.00209 & 0.00314 & -2.5642 & 0.0321 \\
\hline Lrisk. & -0.00265 & 0.0043 & -0.5467 & 02657 & Lrisk. & -0.00897 & 0.00214 & -1.2109 & 0.0453 \\
\hline Nca. & -0.00231 & 0.0275 & -3.1232 & 0.2245 & Nca. & -0.00246 & 0.00231 & -1.4531 & 0.1786 \\
\hline Size & 0.00236 & 0.0645 & 0.2341 & 0.3112 & Size & 0.00213 & 0.00231 & 2.4531 & 0.1453 \\
\hline $\begin{array}{l}\text { Prob(F- } \\
\text { statistic) }\end{array}$ & \multicolumn{4}{|c|}{0} & Prob(F-statistic) & \multicolumn{4}{|c|}{0} \\
\hline $\mathrm{R}^{2}$ & \multicolumn{4}{|c|}{0.899763} & $\mathrm{R}^{2}$ & \multicolumn{4}{|c|}{0.899763} \\
\hline $\begin{array}{l}\text { Durbin- } \\
\text { Watson }\end{array}$ & \multicolumn{4}{|c|}{1.519708} & Durbin-Watson & \multicolumn{4}{|c|}{1.519708} \\
\hline $\begin{array}{l}\text { Hausman } \\
\text { test (FE } \\
\text { vs. RE) }\end{array}$ & \multicolumn{4}{|c|}{0.1978} & $\begin{array}{l}\text { Hausman test } \\
\text { (FE vs. RE) }\end{array}$ & \multicolumn{4}{|c|}{0.1978} \\
\hline
\end{tabular}




\section{CONCLUSION}

Our paper aimed to examine the internal determinants that affect the profitability of $20 \mathrm{GCC}$ commercial banks during the period 2011-2018. We assessed the impact of that bank's level factors on profitability. The dynamic panel data model was adopted to explore the literature on the persistence of profits for banks (POP literature) for the evaluation of bank profitability. We used the estimation of the Random effect model method to investigate banks operating in France. Our results show that profitability is influenced by some factors such as credit risk and capital adequacy. The bank size is also an important determinant of bank's profitability. Therefore, this study supports the previous empirical findings and adds value to financing research that explores the determinants of profitability in the Arabian Gulf banking sector by using top 20 banks as an example. The finding of the study cannot be generalized to represent Gulf banking sector due to the small sample size.

\section{REFRENCES}

1. Eljelly, A. M. (2013). Internal and external determinants of profitability of Islamic banks in Sudan: evidence from panel data. Afro-Asian Journal of Finance and Accounting, 3(3), 222-240.

2. Javaid, S., Anwar, J., Zaman, K., \& Gafoor, A. (2011). Determinants of bank profitability in Pakistan: Internal factor analysis. Mediterranean Journal of Social Sciences, 2(1).

3. Staikouras, C. K., \& Wood, G. E. (2004). The determinants of European bank profitability. International business and economics research journal, 3, 57-68.

4. Athanasoglou, P., Delis, M., \& Staikouras, C. (2006). Determinants of bank profitability in the South Eastern European region.

5. Sufian, F., \& Chong, R. R. (2008). Determinants of bank profitability in a developing economy: empirical evidence from the Philippines. Asian Academy of Management Journal of Accounting \& Finance, 4(2).

6. Alexiou, C., \& Sofoklis, V. (2009). Determinants of bank profitability: Evidence from the Greek banking sector. Ekonomski Anali/Economic Annals, 54(182).

7. Alkassim, F. A. (2005). The profitability of Islamic and conventional banking in the GCC countries: A comparative study. Journal of Review of Islamic Economics, 13(1), 5-30.

8. Bobakova, V. (2003). Possibilities of the increasing of the profitability of a commercial bank. Biatec, 11(4), 26-29.

9. Short, B. K. (1979). The relation between commercial bank profit rates and banking concentration in Canada, Western Europe, and Japan. Journal of banking \& Finance, 3(3), 209219.

10. Bourke, P. (1989). Concentration and other determinants of bank profitability in Europe, North America and Australia. Journal of Banking \& Finance, 13(1), 65-79.

11. Molyneux, P., \& Thornton, J. (1992). Determinants of European bank profitability: A note. Journal of banking \& Finance, 16(6), 1173-1178.

12. Demirgüç-Kunt, A., \& Huizinga, H. (1999). Determinants of commercial bank interest margins and profitability: some international evidence. The World Bank Economic Review, 13(2), 379-408.

13. Hassan Al-Tamimi, H. A. (2010). Factors influencing performance of the UAE Islamic and conventional national banks. Global Journal of Business Research, 4(2), 1-9.

14. Trujillo- Ponce, A. (2013). What determines the profitability of banks? Evidence from Spain. Accounting \& Finance, 53(2), 561-586.

15. Syafri, M. (2012, September). Factors affecting bank profitability in Indonesia. In The 2012 International Conference on Business and Management (Vol. 237, No. 9, pp. 7-8).

16. Bukhari, S. A. J., \& Qudous, R. A. (2012). Internal and external determinant of profitability of banks: Evidence from Pakistan. Interdisciplinary journal of contemporary research in business, 3(9), 1037 1058.

17. Madishetti, S., \& Rwechungura, K. A. (2013). Determinants of bank profitability in a developing economy: empirical evidence from Tanzania. Asian journal of research in banking and finance, 3(11), 46-65.

18. Said, R. M., \& Tumin, M. H. (2011). Performance and financial ratios of commercial banks in Malaysia and China. International Review of Business Research Papers, 7(2), 157-169.

19. Ramadan, I. Z., Kilani, Q. A., \& Kaddumi, T. A. (2011). Determinants of bank profitability: evidance from jordan. International Journal of Academic Research, 3(4).

20. Ani, W. U., Ugwunta, D. O., Ezeudu, I. J., \& Ugwuanyi, G. O. (2012). An empirical assessment of the determinants of bank profitability in Nigeria: Bank characteristics panel evidence. Journal of Accounting and Taxation, 4(3), 38-43.

21. Goddard, J., Molyneux, P., \& Wilson, J. O. (2004). The profitability of European banks: a crosssectional and dynamic panel analysis. The Manchester School, 72(3), 363-381.

22. Gul, S., Irshad, F., \& Zaman, K. (2011). Factors Affecting Bank Profitability in Pakistan. Romanian Economic Journal, 14(39).

23. Pasiouras, F., \& Kosmidou, K. (2007). Factors influencing the profitability of domestic and foreign commercial banks in the European Union. Research in International Business and Finance, 21(2), 222-237.

24. Hoffmann, S., \& Rodrigo, P. (2011). Determinants of the Profitability of the US Banking Industry.

25. Anbar, A., \& Alper, D. (2011). Bank specific and macroeconomic determinants of commercial bank 
Muaadh AYA. Alhabri \& S.N Jha; Saudi J Bus Manag Stud, March., 2020; 5(3): 200-207

profitability: Empirical evidence from Turkey. Business and economics research journal, 2(2), 139-152.

26. Vong, P. I., \& Chan, H. S., (2006), 'Determinants of Bank Profitability in Macau', Journal of Banking and Finance.

27. Gul S, Irshad F, Zaman K (2011). Factors Affecting Bank Profitability in Pakistan, Romanian Econ. J, 14(39): 61-87.
28. Abreu, M. C., Alessandro, B., Alexa, C., Arnaldi, R., Atayan, M., Baglin, C., ... \& Bordalo, P. (2002). Scaling of charged particle multiplicity in $\mathrm{Pb}-\mathrm{Pb}$ collisions at SPS energies. Physics Letters $B, 530(1-4), 43-55$.

29. Micco, A., Panizza, U., \& Yanez, M. (2007). Bank ownership and performance. Does politics matter?. Journal of Banking \& Finance, 31(1), 219241. 